\title{
PEMERINTAHAN YANG CERDAS YANG DIBUTUHKAN DALAM REVOLUSI INDUSTRI 4.O
}

\author{
Samugyo Ibnu Redjo \\ Universitas Padjadjaran Bandung \\ Samugyo.ir@gmail.com
}

\begin{abstract}
Abstrak
Kemajuan ilmu pengetahuan, teknologi komunikasi dan informasi serta perkembangan perekonomian dan perdagangan. Menyebabkan Pemerintah dihadapkan pada massa rakyat yang semakin liberal dan individualis yang cenderung menafikkan keberadaan dan keagungan budaya dan agama. Dan semakin kritis dan rasionalnya massa rakyat yang diindikasikan melalui perhitungan atau pertimbangan untung rugi yang diukur secara ekonomis serta pragmatis. Pragmatisme dan sekularisme dalam kehidupan bermasyarakat di satu sisi, di sisi lain tradisionalisme dan religiusitas masih berkembang subur di masyarakat. Pola berpikir pragmatisme dan sekularisme berakibat pada merapuhnya sikap-sikap toleran antar warga negara. Rakyat cenderung mengelompok pada kesamaan kepentingan ekonomi disamping terus mencari perbedaan dan memilah-milah masyarakat yang didasarkan kepada ukuran-ukuran ekonomis. Oleh karena itu pemerintah harus cerdas untuk mampu menghadapi era globalisasi dan revolusi 4.0 dengan penuh keyakinan dan kepercayaan diri, antara lain adalah bahwa tantangan globalisasi dan revolusi digital tidak mungkin dapat dihindarkan dimana batas-batas antar dan negara sudah semakin transparan.
\end{abstract}

Kata Kunci: Teknologi, ilmu pengetahuan, revolusi 4.0

\section{Abstract}

Advances in science, communication and information technology and economic and trade developments. Cause the Government is confronted with an increasingly liberal and individual mass of people who increasingly deny choosing and grandeur of culture and religion. And the more critical and realistic the mass of the people is indicated through the calculation or assessment of profit and loss needed by finance with pragmatics. Pragmatism and secularism in social life on the one hand, on the other hand traditionalism and religiosity still flourish in the community. Pragmatism and secularism thinking patterns result in tolerance of tolerance among citizens. People who are interested in economic interests in addition to continuing to look for differences and sort out the people who want economic size. Therefore the government must be smart to overcome the era of globalization and the 4.0 revolution with full confidence and confidence, 
among others, the challenges of globalization and the digital revolution are unavoidable where borders between countries and transparencies are now available.

Keywords: Technology, science, revolution 4.0

\section{PENDAHULUAN}

Menghadapi revolusi Industri 4.O, maka pemerintah dihadapkan pada digitalisasi dan hubungan antar Negara yang semakin transparan serta saling mempengaruhi, untuk itu maka yang dibutuhkan adalah suatu Pemerintahan yang memiliki kekuatan dan memiliki kemampuan untuk menerjemahkan tuntutantuntutan rakyat tersebut ke dalam kebijakan-kebijakan pemerintah yang didasarkan pada kemampuan digital. Untuk menterjemahkan tuntutan tuntutan tersebut kedalam kebijakan yang digital, maka dibutuhkan sumberdaya manusia yang cerdas yang memiliki kemampuan untuk menterjemahkan tututan tersebut (Barzelay, 1992).

Dari pandangan diatas, maka yang perlu dilakukan adalah menyiasati kemampuan pemerintahan sehingga dapat mengantisipasi Revulusi Industri 4.O di atas.

Perlu dipahami bahwa tantangan pemerintahan adalah juga merupakan akibat dari perkembangan dan pertumbuhan digitalisasi. Pemerintah dimasa depan adalah pemerintahan digital yang bersandar pada kemampuan E. Govt. (electronic government) dan tidak mungkin menghindarinya. Kemajuan ilmu pengetahuan, teknologi komunikasi dan informasi serta perkembangan perekonomian dan perdagangan. Menyebabkan Pemerintah dihadapkan pada massa rakyat yang semakin liberal dan individualis yang cenderung menafikkan keberadaan dan keagungan budaya dan agama. Dan semakin kritis dan rasionalnya massa rakyat yang diindikasikan melalui perhitungan atau pertimbangan untung rugi yang diukur secara ekonomis serta pragmatis.

Perlu dipahami pula bahwa transformasi sosial yang dialami "Barat" yang bermula dari pertanian (first wave), industri (second wave), dan informasi (third wave), seperti dikemukakan Alvin Toffler dalam Future Shock dan The Third 
Wave terjadi di negara dunia ketiga secara bersamaan, tidak terkecuali di Indonesia. Hal itu disebabkan karena percepatan perubahan yang terjadi khususnya di Indonesia sudah tidak mampu lagi mempertahankan ruang, karena sekat-sekat yang memisahkan antara ketiga gelombang tersebut sudah sangat transparan dan saling connecting.

Hal ini menyebabkan masyarakat Indonesia pun berada di dalam ketiga gelombang tersebut, sehingga tentunya pensiasatan pembangunan harus pula didasarkan kepada indikasi-indikasi ketiga gelombang tersebut. Revolusi Industri 4.O, diindikasikan dengan perkembangan informasi dunia melanda dan menyebar secara mondial yang menyebabkan masyarakat dunia ke tiga, termasuk Indonesia, berada dalam transisi nilai. Nilai masyarakat industri dan nilai-nilai masyarakat informasi belum tumbuh dan adaptif dalam kehidupan masyarakat, sementara nilai-nilai tradisi sudah berangsur ditinggalkan. Akibatnya ukuran penilaian masyarakat atas suatu masalah cenderung bersifat multi dimensi dan sangat bergantung pada pihak-pihak yang mampu menguntungkan secara ekonomis yang diukur dari tampilan materialisme.

Pragmatisme dan sekularisme dalam kehidupan bermasyarakat di satu sisi, di sisi lain tradisionalisme dan religiusitas masih berkembang subur di masyarakat. Pola berpikir pragmatisme dan sekularisme berakibat pada merapuhnya sikap-sikap toleran antar warga negara. Rakyat cenderung mengelompok pada kesamaan kepentingan ekonomi disamping terus mencari perbedaan dan memilah-milah masyarakat yang didasarkan kepada ukuran-ukuran ekonomis.

Kenyataan demikian menyebabkan munculnya masyarakat baru yang dilandasi oleh kepentingan ekonomi dan diikat oleh nilai-nilai ekonomi. Ukuranukuran politik maupun ukuran-ukuran sosial lainnya dinilai dalam standar-standar ekonomi. Konsekuensi pengukuran demikian menyebabkan jabatan-jabatan politik cenderung bermuatan ekonomi, keberadaan seseorang pada jabatan politik dilatarbelakangi oleh suatu kekuatan uang dan modal masyarakat ekonomi dan kemampuan ekonomi individu. Juga keberadaan seseorang dalam jabatan politik 
tidak lepas dari pesan sponsor masyarakat ekonomi tersebut. Hal ini menyebabkan dalam proses-proses politik juga akan diikuti oleh kompetisi ekonomi, yaitu seberapa besar menguntungkan dan merugikannya suatu peraturan terhadap usahausaha ekonominya.

Tantangan seperti dikemukakan di atas, perlu diantisipasi dalam kelembagaan pemerintahan dan dalam menejemen pemerintahan ( Guillart and Kelly, 1997). Untuk itu maka karakteristik-karakteristik pemerintahan yang belum sesuai dengan tuntutan kepamongan berikut selayaknya untuk dihilangkan, dan memunculkan model kelembagaan pemerintahan baru yang lebih antisipatif.

\section{PEMBAHASAN}

\section{Pemerintah Yang Profesional}

Dominannya lembaga pemerintahan memiliki sisi positif dan sisi negatif. Apa-bila dilihat dari sisi positifnya maka hal itu tampak dari lancarnya proses pembangunan dan terkendalinya stabilitas politik. Dan akibatnya adalah pemenuhan kebutuhan dasar rakyat dapat dengan cepat terpenuhi. Akan tetapi sehubungan dengan dominannya lembaga pemerintahan dan kurang adanya check and balances berakibat pada sisi negatif dari pada kerja politik aparatur pemerintahan, Sementara pemerintah profesional yang di harapkan adalah pemerintah yang demokratis, transparan, cerdas dan menguasai informasi dan tekhnologi., yang antara lain :

Pertama, Aparat birokrasi yang profesional yang dicerminkan dari sikap dan perilaku apartur yang melayani dan menghargai pendapat rakyat, cerdas dan mampu menangkap kehendak rakyat dan tidak memaksakan pikiran-pikirannya sendiri.

Kedua, aparatur pemerintah yang cerdas dan tidak memihak. Aparatur pemerintah memiliki tujuan positif untuk memacu proses pertumbuhan sektorsektor lainnya. Akan tetapi dalam proses itu seringkali keberpihakan aparatur pemerintah yang muncul adalah keberpihakan yang dirasakan melanggar "rasa keadilan" yang tumbuh di masyarakat, antara lain melalui, berpindahnya persepsi 
"Kepentingan Umum menjadi Kepentingan Pribadi" dan "Kepentingan Pribadi menjadi Kepentingan Umum". Kasus ini seringkali didengar terutama di kota-kota besar, dimana rakyat di-kalahkan oleh pengusaha dengan alasan kepentingan umum yang kriterianya dimiliki atau dijaga oleh aparatur pemerintah. Dengan kata lain rakyat selalu berada dalam pihak yang kalah.

Ketiga, responsibilitas dan akuntabilitas aparatur pemerintah dalam mengantisipasi dinamika kehidupan rakyat yang sudah semakin pragmatis. Hal itu tidak lain disebabkan oleh kemajuan Ilmu Pengetahuan dan Teknologi, sehingga sekat-sekat antar negara menjadi sangat transparan. Akibatnya tidak ada satupun kejadian yang dapat disembunyikan dari dunia internasional, sehingga kalau muncul isu kolusi, korupsi di kalangan aparatur pemerintah Indonesia di dunia internasional, hal itu tidak lain adalah akibat kemajuan Iptek. Responsibilitas dan akunbilitas aparatur pemerintah ini dapat diindikasikan dari keberdayaannya. Rendahnya keberdayaan akan berakibat rendahnya respon dan tanggung jawab aparatur pemerintah.

Keempat, : Pemerintah yang informatif dan menguasai tekhnologi, sehubungan dengan tantangan globalisasi dan perdagangan bebas maka kelembagaan pemerintah harus memiliki kemampuan untuk menumbuhkan keberdayaan rakyat dalam menghadapi era global.

Kelima, Jadikan lembaga pemerintah sebagai milik publik, sehingga rakyat merasa bahwa kegiatan-kegiatan yang dilakukan oleh pemerintah adalah dalam ke-rangka memberdayakan mereka. Dengan demikian sikap-sikap berpraduga masyarakat terhadap praktek-praktek kolusi maupun korupsi dapat dihapuskan. Untuk itu selayak-nya program-program pemerintah diarahkan kepada memupuk citra pemerintah yang bersih (clean government).

Keenam, Jadikan lembaga pemerintahan sebagai lembaga yang mampu bersaing sehingga tidak kalah oleh sektor prifat. Hal ini dapat dilakukan dengan cara meningkatkan entrepreneurial spirit (semangat kewirausahaan) dalam diri aparatur lembaga pemerintah. Semangat wirausaha ini diproyeksikan dalam hal kecepatan dan ketepatan pelayanan publik sehingga komplain masyarakat terhadap 
kerja aparatur pemerintah yang lamban, birokratis (bertele-tele, berbelit-belit, dan sejenisnya) tidak muncul.

Ketujuh, Lembaga pemerintahan memiliki misi yang jelas. Artinya bahwa kerja lembaga pemerintahan didasarkan kepada keseimbangan peranan antara keharusan menjaga keberlangsungan pembangunan, akan tetapi tidak lepas dari misi utamanya pelayanan publik. Untuk itu maka goals justified the means (tujuan menghalalkan cara) selayaknya tidak dilakukan, karena dengan cara yang baik akan didapatkan hasil yang baik.

Kedelapan, Jadikan lembaga pemerintahan berorientasi kepada hasil atau prestasi. yaitu bahwa setiap dana yang dikeluarkan harus diorientasikan kepada hasil yang ingin dicapai. Dalam istilah lain bahwa untuk "memancing uang" harus dengan "umpan uang". Dan untuk itu pertimbangan ekonomis selayaknya di perhitungkan, sehingga hasilnya dapat diperkirakan.

Kesembilan, Lembaga pemerintahan mengutamakan pelayanan terhadap publik. Maksudnya adalah lembaga pemerintahan harus memiliki kemampuan untuk mensejajarkan diri dengan pihak-pihak swasta dalam hal menarik simpati publik dalam hal pemberian pelayanan. Oleh sebab itu maka model aparatur pemerintah yang minta dilayani sudah selayaknya diubah menjadi aparatur pemerintah yang melayani.

Kesepuluh, Aparatur pemerintah sudah selayaknya memiliki kualifikasi profesional sehingga memiliki kemampuan untuk mengantisipasi berbagai perubahan yang diperkirakan akan terjadi. Dengan demikian maka tuntutan untuk peningkatan kualitas sumber daya manusia harus merupakan prioritas pemerintah menghadapi era globalisasi.

\section{Strategi Untuk Membangun Smart Government}

Dalam membangun kota/pemerintah cerdas (Smart Government), seyogyanya pemerintah memfokuskan pada strategi strategi berikut 


\section{Strategy Visi}

Dalam strategy inti ini, terdapat tiga pendekatan yang dapat digunakan, yaitu kejelasan maksud/tujuan, kejelasan peran, kejelasan arah. Disebut sebagai "Inti" karena strategi ini berhubungan dengan fungsi utama dari pihak pemerintah, yaitu fungsi mengarahkan (steering). Penekanan perbaikan kemampuan mengarahkan ini menjadi fokus utama strategi ini relatif terhadap keempat strategi lainnya yang lebih bersifat memperbaiki kemampuan menggerakkan pembangunan itu sendiri.

\section{Strategy Misi dan Akibat}

Strategi kedua ini mempunyai beberapa pendekatan, yaitu pengelolaan kompetisi, manajemen organisasi/kelembagaan, dan manajemen kinerja. Pada prinsipnya, dalam strategi ini menekankan pentingnya pasar dan kompetisi dalam penciptaan insentif dan oleh karenanya juga perbaikan besar dalam kinerja. Oleh karena itu, harus dipikirkan dengan cermat, dalam hal-hal apa pihak pemerintah masih harus dominan dalam pembangunannya, dan dalam hal apakah hal tersebut harus dipercayakan kepada pasar bebas yang dalam hal ini para investor swasta. Tolok ukur utama yang dipakai tentunya sistem pembangunan yang mana menghasilkan kinerja pembangunan wilayah yang lebih baik.

\section{Strategy Pelanggan}

Penekanan utama strategi ini adalah pada akuntabilitas, yang dapat didekati dengan beberapa pendekatan, yaitu pilihan pengguna/costumer, pilihan kompetitif, dan jaminan kualitas pengguna (costumer quality assurance) Dalam hal ini kepuasan pengguna (dalam artian para investor maupun masyarakat luas) menjadi hal utama yang harus dicapai.

\section{Strategy pengendalian}

Dalam strategi ini sistem kontrol ditekankan pada pendelegasian wewenang yang jelas dan terarah atas semua stakeholders yang terlibat dalam 
pengambilan keputusan pembangunan. Pendekatan yang dapat dilakukan adalah dengan pemberdayaan organisasi/institusi, pemberdayaan pekerja, dan pemberdayaan masyarakat/komunitas. Seharusnya dihindarkan aturan yang sangat rinci dan sistem perintah yang sangat hierarkis tetapi harus diciptkan misi-misi bersama sebagai acuan dan sistem yang membentuk akuntabilitas untuk kinerja. Hal ini juga memberdayakan organisasi pembangunan dengan memberikan kebebasan yang cukup untuk bergerak sesuai dengan kondisi dan atau situasi yang ada, memberdayakan para praktisi untuk membuat keputusan, merespon pengguna/masyarakat, dan menyelesaikan permasalahan berdasarkan pengetahuan-pengetahuan lapangan terdepan yang dimiliki. Selain itu juga, dapat dilakukan dengan memberikan kepercayaan kepada anggota masyarakat dan organisasi untuk menyelesaikan permasalahan mereka sendiri dan menjalankan institusi mereka sendiri.

\section{Strategy Budaya.}

Sesuai dengan namanya, maka strategi ini menekankan pada perubahan sikap dan prilaku/budaya dari para stakeholders pembangunan. Pendekatan yang dapat dilakukan adalah dengan mengubah kebiasaan serta menyentuh hati dan perasaaan untuk mengubah komitmen emosional mereka bagi pembangunan. Kondisi ini juga harus didukung dengan penyusunan bersama mengenai masa depan, model mental di mana komunitas akan terbentuk, dan bagaimana hal itu harus dicapai.

\section{KESIMPULAN}

Dari pemaparan di atas, maka perlu diantisipasi oleh pemerintah cerdas untuk mampu menghadapi era globalisasi dan revolusi 4.0 dengan penuh keyakinan dan kepercayaan diri, antara lain adalah bahwa tantangan globalisasi dan revolusi digital tidak mungkin dapat dihindarkan dimana batas-batas antar dan negara sudah semakin transparan. Dan hal ini berakibat pada saling pengaruh dan saling ketergantungan yang tinggi antar negara dan antar rakyat. Untuk itu maka 
karakteristik-karakteristik negatif dari lembaga pemerintahan selayaknya untuk dibuang, disamping menyiasati pemerintahan yang diharapkan publik yang mampu memberdayakan rakyat.

Tantangan pemerintahan yang kondusif tersebut di atas, mengharuskan kita berpikir bahwa "semakin mengglobal suatu pemerintahan, maka semakin besar tantangan yang dihadapi. Dan semakin besar tantangan yang dihadapi, berarti semakin dibutuhkan resources yang mampu menghadapi tantangan tersebut. Itulah Smart government

\section{DAFTAR PUSTAKA}

Breton, Albert, Competitive Government, An Economic Theory of Politics and Public Finance., Cambridge University Press, 1998.

Denhard, Janet V and Denhard, Robert.B., The New Public Service, serving not steering., M.E. Sharpe, New York, 2003

Osborne, David \& Peter Plastrik. Banishing Bureaucracy: The Five Strategies for Reinventing Government. Masachusetts: Addison Wesley. 1996

Osborne, David and Ted Gaebler. Reinventing Government: How The Entrepreneurial Spirit is Transforming The Public Sector. Reading, MA: Addison-Wesley Publishing Company, Inc., 1993.

Turner, Mark and Hulme David., Governance, Administration and Development ., making the state work, .Palgrave, 1997. 